\title{
ANALISIS KEMAMPUAN BERPIKIR KREATIF MATEMATIS SISWA KELAS XII MIA SMA NEGERI 2 KOLAKA
}

\author{
Marniati $^{1}$, Nasruddin $^{1 *}$, Nurhafifah $^{2}$ \\ ${ }^{1,2}$ Program StudiPendidikanMatematikaUniversitasSembilanbelas November Kolaka \\ bungaitb@gmail.com \\ nash.matematika@gmail.com \\ nurhafifah16030286@gmail.com
}

\begin{abstract}
This study aims to describe the mathematical creative thinking ability of class XII MIA students of SMA Negeri 2 Kolaka. This type of research is qualitative descriptive with research subjects consisting of 37 students of class XII MIA SMA Negeri 2 Kolaka. The reserch instrument consisted of a written test in consisting of 3 questions and interviews in which the data were grouped and analized according to the indicators of creative thinking abilities. Based on the results of the students' mathematical creative thinking ability test results showed thet out of 37 respondents there was 1 respondent with very creative thinking skills, 8 rspondents were creative, 11 respondents were creative enough, 15 respondents were less creative, and 2 respondents were not creative. Based on the results of data analysis, it was obtained: (1) The flexibility indicatoor is $44,46 \%$; (2) Fluency is $44,93 \%$; (3) Originality of 51,69\%; (4) Elaboration of 46,12\%. The result showed that the average mathematical creative thinking ability of stundents of class XII MIA for all indicators was in the quite creative category with a percentage of $46,12 \%$.
\end{abstract}

Keywords: Creative Thinking

\begin{abstract}
Abstrak
Penelitian ini bertujuan untuk mendeskripsikan kemampuan berpikir kreatif matematis siswa kelas XII MIA SMA Negeri 2 Kolaka. Jenis penelitian ini adalah deskriptif kualitatif dengan subjek penelitian terdiri dari 37 siswa kelas XII MIA SMA Negeri 2 Kolaka. Instrumen penelitian ini terdiri dari tes tulis yang terdiri dari 3 soal dan wawancara yang selanjutnya data dikelompokkan dan dianalisis sesuai dengan indicator kemampuan berpikir kreatif. Berdasarkan hasil tes kemampuan berpikir kreatif matematis siswa menunjukkan dari 37 responden terdapat 1 responden dengan kemampuan berpikir kategori sangat kreatif, 8 responden kategori kreatif, 11 responden kategori cukup kreatif, 15 responden kategori kurang kreatif, dan 2 responden kategori tidak kreatif. Berdasarkan hasil analisis data, diperoleh: (1) Indikator keluwesan yaitu sebesar 44,46\%; (2) Kelancaran yaitu sebesar 44,93\%; (3) Keaslian sebesar 51,69\%; (4) Elaborasi sebesar 46,12\%. Hasil penelitian menunjukkan rata-rata kemampuan berpikir kreatif matematis siswa kelas XII MIA untuk semua indicator berada pada kategori cukup kreatif dengan persentase sebesar 46,12\%.
\end{abstract}

Kata kunci: Berpikir Kreatif

Cara Menulis Sitasi: Marniati., Nasruddin., \& Nurhafifah (2020). Analisis Kemampuan Berpikir Kreatif Matematis Siswa Kelas XII MIA SMA Negeri 2 Kolaka. Mathematic Education and Aplication Journal, 2(2), 25-36.

Pendidikan memiliki peranan yang sangat penting dalam kehidupan manusia. Salah satu unsur paling penting dalam pendidikan adalah pembelajaran. Kecenderungan pembelajaran di era sekarang yaitu dapat dimana saja, kapan saja, dengan siapa saja, dan melalui sumber apa saja (Muadiarti, Suma, \& Prawiradilaga, 2015). Pendidikan pada dasarnya bermaksud membantu peserta didik untuk memperdayakan potensi dalam dirinya atau menumbuhkembangkan potensi-potensi kemanusiaannya (Neolaka \& Neolaka, 2017).

Matematika dalam dunia pendidikan merupakan salah satu ilmu dasar yang dapat digunakan 
untuk menunjang ilmu-ilmu lain seperti fisika, kimia, komputer, dan lain-lain. Matematika sebagai salah satu disiplin ilmu yang diajarkan pada setiap jenjang pendidikan sekolah, diharapkan dapat memberikan sumbangan dalam rangka mengembangkan kemampuan berpikir kritis, sistematis, logis, kreatif, dan bekerja sama secara efektif. Sejalan dengan hal tersebut Fatwa, Septian, dan Inayah (2019) mengatakan bahwa kemampuan berpikir matematis yang sangat diperlukan siswa terangkum dalam kemampuan berpikir kritis, pemecahan masalah, penalaran matematis, dan berpikir kreatif matematis perlu mendapat perhatian lebih pada proses pembelajaran. Sikap dan cara berpikir seperti ini dapat dikembangkan melalui pembelajaran matematika, karena matematika memiliki struktur dan keterkaitan yang kuat dan jelas antar konsepnya sehingga memungkinkan siapapun yang mempelajarinya terampil dalam berpikir secara rasional dan siap mengahdapi permasalahan (Setiawan, 2012; Nasruddin, 2020).

Kemampuan berpikir kreatif merupakan kemampuan yang dikategorikan sebagai kemampuan berpikir tingkat tinggi atau HOTS (High Order Thinking Skill). HOTS menjadi salah satu tujuan dari kurikulum 2013 yang harus dicapai oleh siswa (Gais \& Afriansyah, 2017). Hal tersebut menunjukkan bahwa pentingnya kemampuan berpikir kreatif dalam bidang matematis (Nasruddin, 2019). Berpikir kreatif merupakan kemampuan seseorang mengembangkan pemikirannya mengenai sesuatu yang baru, menciptakan dan mengembangkan ide atau gagasan yang sudah ada menjadi suatu hal yang luar biasa (Nurfitria \& Nindiasari, 2018). Sejalan dengan hal tersebut, Eragamreddy (2013) mengemukakan bahwa kreativitas atau berpikir kreatif menggunakan jenis pemikiran yang mengarah pada wawasan baru, perspektif baru, keseluruhan cara baru untuk memahami pemikiran lainnya. Sesuatu yang baru disini tidak harus berupa hasil atau ciptaan yang benar-benar baru walaupun hasil akhirnya mungkin akan tampak sebagai sesuatu yang baru, tetapi dapat berupa hasil penggabungan dua atu lebih konsep-konsep yang sudah ada. Ketika siswa telah mampu mengkreativitaskan beberapa ide matematis, maka siswa dapat memperoleh pemahaman yang lebih baik.

Faktanya kemampuan siswa Indonesia masih berada di bawah standar internasional. Hal tersebut didasarkan pada hasil studi TIMSS (Trends in International Mathematic and Science Study) pada tahun 2015 menunjukkan bahwa pada bidang matematika, Indonesia berada pada peringkat 45 dari 50 negara. Berdasarkan hasil studi tersebut dapat disimpulkan bahwa prestasi matematika siswa di Indonesia masih tergolong rendah. Soal-soal matematika dalam studi TIMSS mengukur tingkat kemampuan siswa dari sekedar mengetahui fakta, prosedur atau konsep hingga menggunakannya untuk memecahkan masalah sederhana sampai masalah yang memerlukan penalaran tinggi (Sari, 2015). Menghadapi soal-soal tersebut siswa dituntut untuk berpikir kritis dan kreatif.

Berdasarkan hasil observasi yang dilakukan di kelas XII MIA SMANegeri 2 Kolaka dapat diidentifikasi bebrapa kelemahan siswa, antara lain: tidak lancar menggunakan pengetahuan atau ideide yang diketahui, mengubah kalimat cerita menajdi kalimat matematika, menggunakan cara-cara atau strategi-strategi yang berbeda-beda dalam merencanakan penyelesaian suatu masalah, tidak dapat membedakan informasi yang diketahui dan permintaan soal, dan tidak dapat mengambil kesimpulan 
atau mengembalikan ke masalah yang dicari. Apabila dipersempit kelemahan itu terutama pada kemampuan siswa memehami dan merencanakan suatu penyelesaian. Dalam memahami maupun merencanakan penyelesaian masalah diperlukan kekmampuan berpikir kreatif siswa yang memadai, karena kemampuan tersebut merupakan kemampuan berpikir (bernalar) tingkat tinggi setelah dasar (basic) dan kritis.

Beberapa penelitian tentang kemampuan berpikir kreatif, diantaranya penelitian yang dilakukan oleh Putra, dkk (2017) menyimpulkan bahwa kemampuan berpikir kreatif siswa sebagian besar berada pada kategori cukup kreatif (sedang). Sementara itu, penelitian yang dilakukan oleh Rasnawati, dkk (2019) dan Rachman dan Amelia (2020) menyimpulkan bahwa kemampuan berpikir kreatif matematis siswa masih tergolong rendah.Berdasarkan uraian di atas penelitian ini memiliki tujuan untuk mendeskripsikan kemampuan berpikir kreatif matematis siswa kelas XII MIA SMA Negeri 2 Kolaka.

\section{METODE}

Jenis penelitian ini adalah penelitian deskriptif kualitatif. Penelitian ini dilaksanakan di SMA Negeri 2 Kolaka kelas XII MIA berjumlah 37 orang. Instrumen dalam penelitian ini adalah tes kemampuan berpikir kreatif matematis siswa materi barisan dan deret dan pedoman wawancara. Proses triangulasi yang digunakan adalah triangulasi sumber, dimana hasil dari subjek dicari kesamaan dan perbedaannya.

Setelah data jawaban tertulis dikelompokkan pada kategori menurut Idrisah (2014) seperti Tabel 1. Langkah selanjutnya yaitu pemilihan subjek menggunakan purposive sampling. Masingmasing kategori dipilih satu subjek sehingga diperoleh 5 subjek. Kemudian melihat kekonsistenan data profil berpikir kreatif matematis subjek dengan mensingkronkan data wawancara menggunakan triangulasi sumber. Selanjutnya membuat kesimpulan dengan menjumlahkan skor pada masingmasing indikator.Analisis data wawancara menggunakan beberapa tahapan, antara lain: (1) mereduksi data, (2) pemaparan data, dan (3) penarikan kesimpulan.

Tabel 1. Kategori Kemampuan Berpikir Kreatif

\begin{tabular}{|c|c|}
\hline Keberhasilan Tindakan (\%) & Kriteria \\
\hline $81 \leq P K \leq 100$ & Sangat Kreatif \\
\hline $61 \leq P K<81$ & Kreatif \\
\hline $41 \leq P K<61$ & Cukup Kreatif \\
\hline $21 \leq P K<41$ & Kurang Kreatif \\
\hline$P K<21$ & Tidak Kreatif \\
\hline
\end{tabular}




\section{HASIL DAN PEMBAHASAN}

\section{Analisis data kemampuan berpikir kreatif siswa}

Berdasarkan hasil tes kemampuan berpikir kreatif matematis siswa kelas XII MIA Negeri 2 Kolaka diperoleh hasil pada Tabel 2.

Tabel 2. Interpretasi kemampuan berpikir kreatif matematis siswa

\begin{tabular}{|c|c|c|c|}
\hline Interval & Frekuensi & Persentase & Interpretasi \\
\hline $81 \leq P K \leq 100$ & 1 & $2,70 \%$ & Sangat Kreatif \\
\hline $61 \leq P K<81$ & 8 & $21,62 \%$ & Kreatif \\
\hline $41 \leq P K<61$ & 11 & $29,73 \%$ & Cukup Kreatif \\
\hline $21 \leq P K<41$ & 15 & $40,54 \%$ & Kurang Kreatif \\
\hline$P K<21$ & 2 & $5,41 \%$ & Tidak Kreatif \\
\hline
\end{tabular}

Berdasarkan tabel 2 dari 37 siswa kelas XII MIA yang diberikan tes mengenai soal barisan dan deret diperoleh bahwa siswa yang memiliki kemampuan berpikir sangat kreatif hanya terdapat 1 orang, 8 siswa termasuk kategori berpikir kreatif, 11 siswa cukup kreatif, 15 siswa kurang kreatif, dan 2 siswa tidak kreatif. Sementara itu, untuk mendeskripsikan kemampuan berpikir kreatif siswa dalam menyelesaikan tiap soal pada barisan dan deret dianalisis berdasarkan indikator kemampuan berpikir kreatif diperoleh pada Tabel 3 berikut.

Tabel 3. Persentase kemampuan berpikir kreatif matematis siswa per indikator soal

\begin{tabular}{|c|c|}
\hline Indikator & Frekuensi \\
\hline Kelancaran & 44,93 \\
\hline Keluwesan & 44,46 \\
\hline Keaslian & 51,69 \\
\hline Elaborasi & 43,41 \\
\hline Rata-rata & $\mathbf{4 6 , 1 2}$ \\
\hline
\end{tabular}

Berdasarkan tabel 3 tersebut menunjukkan bahwa indiaktor keaslian memiliki persentase tertinggi sebesar 51,69\% sehingga dapat dikategorikan cukup baik dibandingkan dengan indikator lainnya. Sedangkan persentase terendah diperoleh pada indikator elaborasi sebesar 43,41\%. Berdasarkan perolehan persentase dari 4 indikator kemampuan berpikir kreatif matematis siswa kelas XII MIA SMA Negeri 2 Kolaka berada pada kategori cukup kreatif yaitu sebesar 46,12\%.

\section{Analisis kemampuan berpikir kreatif subjek kategori sangat kreatif $\left(\mathbf{S}_{1}\right)$}

\section{a. Indikator keluwesan}

Indikator keluwesan terdiri dari soal $1 \mathrm{a}, 2 \mathrm{a}$, dan $3 \mathrm{a} . \mathrm{S}_{1}$ menyelesaikan soal $1 \mathrm{a}$ dan $3 \mathrm{a}$ menggunakan lebih dari satu cara penyelesaian dan pada proses perhitungan diperoleh hasil yang benar. Sementara itu, pada soal nomor $2 \mathrm{a}, \mathrm{S}_{1}$ hanya menyelesaikan dengan satu cara diperkuat denga hasil wawancara dengan $S_{1}$. Terlihat bahwa $S_{1}$ tidak mengetahui cara lain untuk menyelesaikan soal 2a. Triangulasi dari hasil tes tulis dan wawancara diperoleh bahwa $S_{1}$ mampu menyelesaikan permsalahan menggunakan lebih dari satu penyelesaian dan pada proses perhitungan memperoleh 
hasil yang benar.Adapun transkrip wawancara $S_{1}$ untuk indikator keluwesan sebagai berikut.

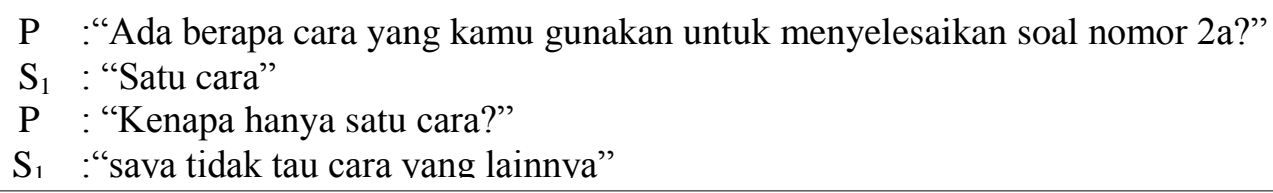

\section{b. Indikator kelancaran}

Pada indikator kelancaran terdiri dari soal nomor $1 b, 2 b$, dan $3 c . S_{1}$ menyelesaikan soal $1 b$, $2 \mathrm{~b}$, dan $3 \mathrm{c}$ menggunakan lebih dari satu ide yang relevan pada soal.Transkrip wawancara terlihat bahwa $S_{1}$ menyelesaikan dengan memberikan lebih dari satu ide yang relevan pada soal. Selain itu, penyelesaian jawaban $S_{1}$ benar dan jelas. Berdasarkan triangulasi dari hasil tes dan wawancara, dapat dikatakan bahwa $S_{1}$ mampu memberikan lebih dari satu ide yang relevan, penyelesaian benar dan jelas. Adapun transkrip wawancara untuk indikator kelancaran sebagai berikut.

P :"Berapa jawaban dari soal bagian b?"

$\mathrm{S}_{1}$ : " 8000 bakteri"

P :"Bagaimana kamu bisa mendapatkan hasil 8000 bakteri?"

$S_{1}$ :"Diketahui bakteri berlipat ganda pada saat 2 jam pertama di dapat 2400 bakteri tetapi mati 400 sisa 2000 bakteri dan dikali 2 dapat 4000 . Kemudian dikali 2 lagi daptlah 8000 bakteri"

\section{c. Indikator elaborasi}

Soal indikator elaborasi yang terdiri dari soal nomor 1c, 2c, dan 3d. $S_{1}$ menyelesaikan soal 2c, dan 3d menggunakan jawaban yang benar dan rinci. Sementara itu, pada soal nomor 1c $S_{1}$ tidak mampu memberikan jawaban yang benar dan tidak disertai perincian yang jelas terlihat pada Gambar 1. Pada transkrip wawancara terlihat bahwa $S_{1}$ menyelesaikan soal nomor 1c tidak sistematis, $S_{1}$ menjawab sesuai yang dipahami tetapi tidak yakin dengan jawaban yang diberikan. Berdasarkan triangulasi dari hasil tes dan wawancara, dapat dikatakan bahwa $S_{1}$ kurang mampu memberikan jawaban yang benar dan rinci.

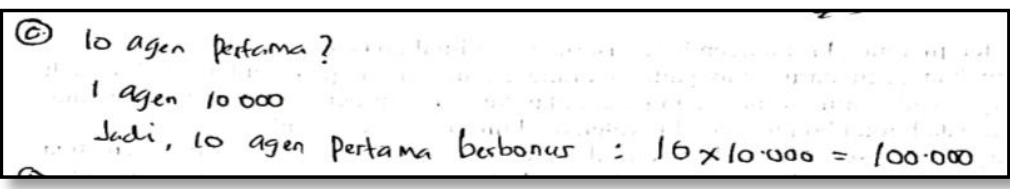

Gambar 1. Pekerjaan S1 pada soal nomor 1c

\section{d. Indikator keaslian}

Indikator keaslian terdiri dari soal $1 \mathrm{~d}, 2 \mathrm{~d}$, dan $3 \mathrm{~b} . \mathrm{S}_{1}$ menyelesaikan soal $1 \mathrm{~d}$ dan $3 \mathrm{~b}$ menggunakan cara penyelesaian sendiri, proses perhitungan dan hasilnya benar. Sementara itu, pada soal nomor $2 \mathrm{~d} \mathrm{~S}_{1}$ memberikan jawaban dengan cara sendiri, namun terdapat kekeliruan dalam proses perhitungan sehingga hasilnya salah. Pada transkrip wawancara terlihat bahwa $S_{1}$ menyelesaikan soal nomor $2 \mathrm{~d}$ sesuai dengan pemikiran sendiri berbeda dengan penyelesaian yang biasa didapatkan. Triangulasi dari hasil tes tulis dan wawancara diperoleh bahwa $S_{1}$ mampu memberi jawaban dengan cara penyelesaian sendiri.Adapun transkrip wawancara untuk indikator keaslian sebagai berikut. 


$$
\begin{aligned}
& \mathrm{P}: \text { : Apakah ada jawaban kamu yang tidak diselesaikan secara sistematis?" } \\
& \mathrm{S}_{1} \text { : "Ada, saya kerjakan sesuai dengan pemikiran sendiri" } \\
& \mathrm{P}: \text { :Apakah jawaban kamu sudah sering dijumpai dalam penyelesaian soal?" } \\
& \mathrm{S}_{1} \text { : "Tidak" } \\
& \mathrm{P} \text { : "Kira-kira jawaban kamu sama dengan teman yang lain?" } \\
& \mathrm{S}_{1} \text { : "Tidak" }
\end{aligned}
$$

\section{Analisis kemampuan berpikir kreatif subjek kategori kreatif $\left(\mathbf{S}_{2}\right)$}

\section{a. Indikator keluwesan}

Indikator keluwesan terdiri dari soal $1 \mathrm{a}, 2 \mathrm{a}$, dan $3 \mathrm{a} . \mathrm{S}_{2}$ menyelesaikan soal 1a dan 3a menggunakan lebih dari satu cara penyelesaian dan pada proses perhitungan diperoleh hasil yang benar. Sementara itu, pada soal nomor $2 \mathrm{a} \mathrm{S}_{2}$ hanya menyelesaikan dengan satu cara dapat dilihat pada Gambar 2. Transkrip wawancara $S_{2}$ terlihat bahwa $S_{2}$ menyelesaikan soal nomor 2a menggunakan satu cara karena kesulitan dalam mencari cara lain. Triangulasi dari hasil tes tulis dan wawancara diperoleh bahwa $S_{2}$ mampu menyelesaikan permasalahan menggunakan lebih dari satu penyelesaian dan pada proses perhitungan memperoleh hasil yang benar.

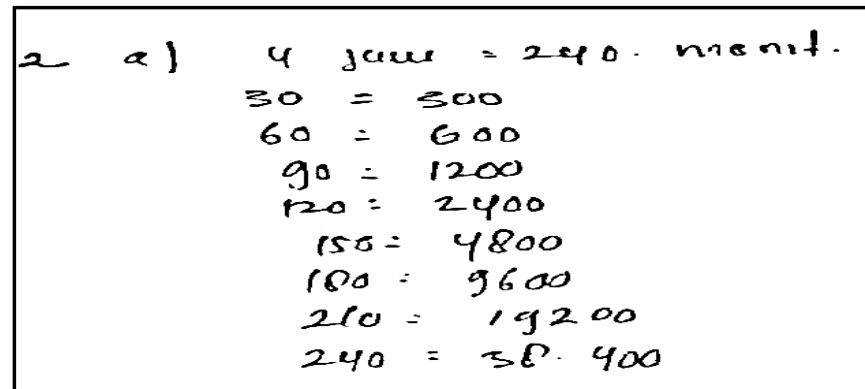

Gambar 2. Pekerjaan $\mathrm{S}_{2}$ soal nomor 2a

\section{b. Indikator kelancaran}

Soal untuk indikator kelancaran terdiri dari soal nomor $1 \mathrm{~b}, 2 \mathrm{~b}$, dan $3 \mathrm{c} . \mathrm{S}_{2}$ menyelesaikan soal $1 \mathrm{~b}$ menggunakan lebih dari satu ide yang relevan. Pada soal nomor $2 \mathrm{~b} \mathrm{~S}_{2}$ tidak memberikan lebih dari satu ide yang relevan, serta jawaban yang diberikan masih terdapat kesalahan. Sedangkan pada soal nomor 3c, $\mathrm{S}_{2}$ memberikan lebih dari satu ide yang relevan, tetapi hasil perhitungan masih terdapat kekeliruan. Pada Gambar 3 dan transkrip wawancara terlihat bahwa $S_{2}$ menyelesaikan dengan cara mencari terlebih dahulu nilai suku-sukunya, kemudian menjumlahkan suku-suku tersebut. Berdasarkan triangulasi dari hasil tes dan wawancara, dapat dikatakan bahwa $S_{2}$ kurang mampu memberikan lebih dari satu ide yang relevan, penyelesaian benar dan jelas.

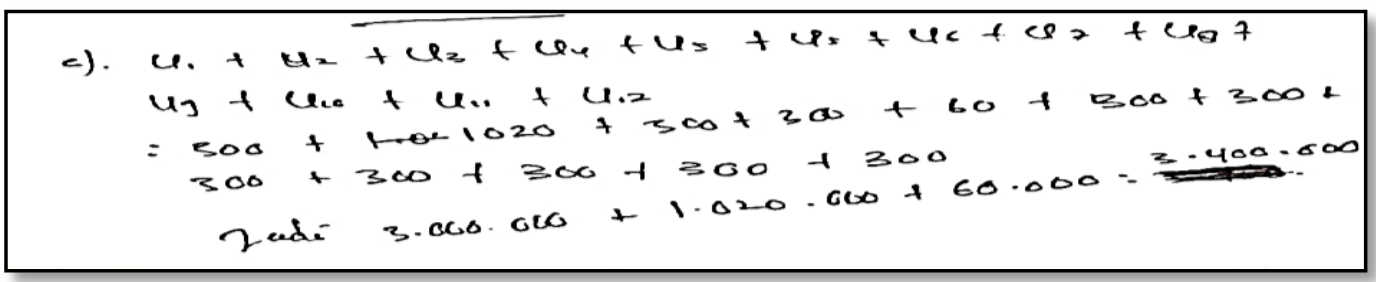

Gambar 3. Pekerjaan $\mathrm{S}_{2}$ soal nomor 3c 


\section{c. Indikator elaborasi}

Indikator elaborasi terdiri dari soal nomor $1 \mathrm{c}, 2 \mathrm{c}$, dan 3d. $\mathrm{S}_{2}$ tidak menyelesaikan permasalahan secara sistematis, terdapat kesalahan dalam jawaban dan tidak disertai perincian yang jelas. Transkrip wawancara terlihat bahwa $S_{2}$ menyelesaikan soal sistematis, tetapi masih terdapat kesalahan dalam jawaban. Berdasarkan triangulasi dari hasil tes dan wawancara, dapat dikatakan bahwa $S_{2}$ kurang mampu memberikan jawaban yang benar dan rinci.

\section{d. Indikator keaslian}

Indikator keaslian terdiri dari soal 1d, 2d, dan $3 \mathrm{~b}$. Soal nomor $2 \mathrm{~d} \mathrm{~S}_{2}$ memberikan jawaban dengan cara sendiri, namun terdapat kekeliruan dalam proses perhitungan sehingga hasilnya salah. Setelah dilakukan wawancara, $\mathrm{S}_{2}$ menyelesaikan soal nomor $2 \mathrm{~d}$ sesuai dengan pemikiran sendiri berbeda dengan penyelesaian yang biasa didapatkan. Triangulasi dari hasil tes tulis dan wawancara diperoleh bahwa $\mathrm{S}_{2}$ mampu memberi jawaban dengan cara penyelesaian sendiri.

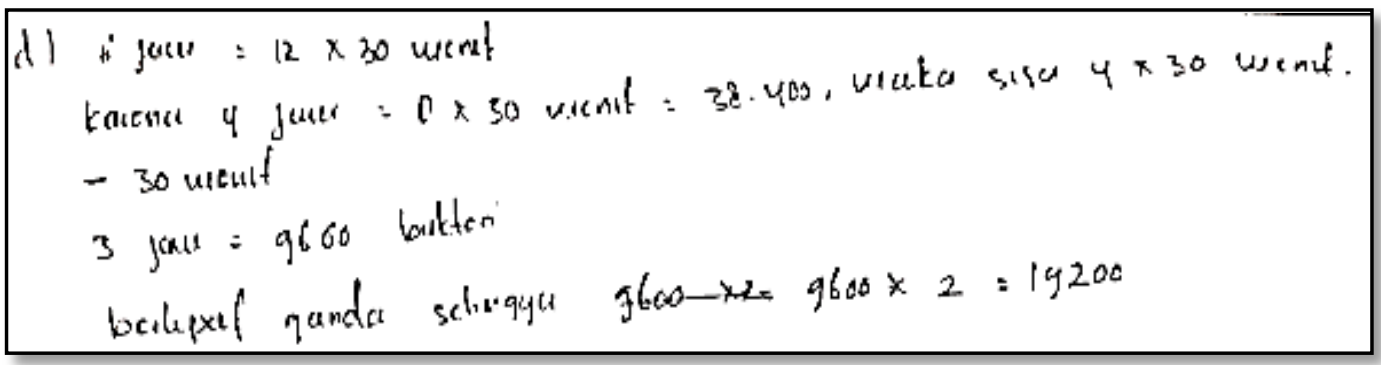

Gambar 4. Pekerjaan $\mathrm{S}_{2}$ soal nomor 2d

\section{Analisis kemampuan berpikir kreatif subjek kategori cukup kreatif (S3)}

\section{a. Indikator keluwesan}

Indikator keluwesan terdiri dari soal $1 \mathrm{a}, 2 \mathrm{a}$, dan $3 \mathrm{a} . \mathrm{S}_{3}$ menyelesaikan soal 1a dan $3 \mathrm{a}$ menggunakan satu cara penyelesaian dan pada proses perhitungan diperoleh hasil yang benar. Sementara itu, pada soal nomor 2a S3 tidak memberikan jawaban apapun pada soal. Transkrip wawancara $\mathrm{S}_{3}$ terlihat bahwa $\mathrm{S}_{3}$ tidak menyelesaikan soal nomor 2a karena tidak mengetahui maksud dari soal. Triangulasi dari hasil tes tulis dan wawancara diperoleh bahwa $S_{3}$ kurang mampu menyelesaikan permasalahan menggunakan lebih dari satu penyelesaian dan pada proses perhitungan memperoleh hasil yang benar.

\section{b. Indikator kelancaran}

Adapun soal untuk indikator kelancaran terdiri dari soal nomor $1 \mathrm{~b}, 2 \mathrm{~b}$, dan $3 \mathrm{c} . \mathrm{S}_{3}$ menyelesaikan soal $1 \mathrm{~b}$ dan $2 \mathrm{~b}$ menggunakan lebih dari satu ide yang relevan. Sedangkan pada soal nomor $3 c \mathrm{~S}_{3}$ memberikan jawaban dengan ide yang tidak relevan, serta jawaban yang diberikan masih terdapat kesalahan. Pada transkrip wawancara terlihat bahwa $S_{3}$ menyelesaikan menyelesaikan menggunakan rumus barisan aritmetika dan tidak yakin dengan jawaban yang diberikan. Berdasarkan triangulasi dari hasil tes dan wawancara, dapat dikatakan bahwa $S_{3}$ kurang mampu memberikan lebih 
dari satu ide yang relevan, penyelesaian benar dan jelas. Adapun transkrip wawancara untuk indikator kelancaran sebagai berikut.

P :"Jelaskan bagaimana kamu menyelesaiakan bagian c!"

$\mathrm{S}_{3}$ :"Saya gunakan rumus lagi seperti bagian a, masukkan nilai yang diketahui baru dikerjakan kemudian dapat $750 "$

P :"Apakah kamu yakin dengan jawabanmu?"

$\mathrm{S}_{3}$ : "Tidak"

P : "Kenapa tidakyakin?"

$\mathrm{S}_{3}$ : "Saya kurang paham maksud dari soal"

\section{c. Indikator elaborasi}

Adapun soal untuk indikator elaborasi terdiri dari soal nomor 1c, 2c, dan 3d. Pada Gambar 5 terlihat bahwa $S_{3}$ menyelesaikan soal nomor 1c secara sistematis tetapi terdapat kesalahan dalam jawaban dan disertai perincian yang rinci. Sementara itu, pada soal nomor $2 c S_{3}$ tidak memberikan jawaban apapun pada soal tersebut. Pada soal nomor $3 \mathrm{~d}, \mathrm{~S}_{3}$ tidak menyelesaikan permasalahan secara sistematis, terdapat kesalahan dalam jawaban dan tidak disertai perincian yang jelas Transkrip wawancara terlihat bahwa $S_{3}$ menyelesaikan soal secara sistematis, tetapi masih terdapat kesalahan dalam jawaban dan disertai penjelasan yang kurang detail. Berdasarkan triangulasi dari hasil tes dan wawancara, dapat dikatakan bahwa S3 tidak mampu memberikan jawaban yang benar dan rinci.

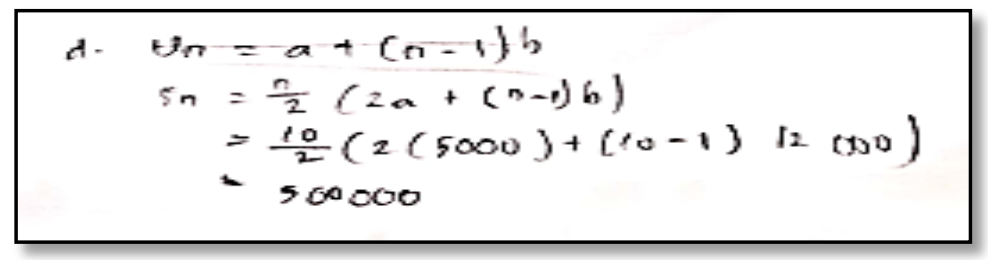

Gambar 5. Pekerjaan $\mathrm{S}_{3}$ soal nomor 3d

\section{d. Indikator keaslian}

Indikator keaslian terdiri dari soal $1 \mathrm{~d}, 2 \mathrm{~d}$, dan $3 \mathrm{~b} . \mathrm{S}_{3}$ menyelesaikan soal $1 \mathrm{~d}$ menggunakan cara penyelesaian sendiri, proses perhitungan dan hasilnya benar. Sementara itu, pada soal nomor $2 \mathrm{~d}$ $\mathrm{S}_{3}$ tidak memberikan jawaban. Soal nomor $3 \mathrm{~b}$ menyelesaikan dengan cara sendiri namun masih terdapat kekeliruan dalam proses perhitungan sehingga hasilnya kurang tepat. Pada transkrip wawancara $S_{3}$ terlihat bahwa $S_{3}$ menyelesaikan soal nomor $3 b$ menggunakan rumus yang telah didapatkan sebelumnya. Triangulasi dari hasil tes tulis dan wawancara diperoleh bahwa $S_{3}$ kurang mampu memberi jawaban dengan cara penyelesaian sendiri.

\section{Analisis kemampuan berpikir kreatif subjek kategori kurang kreatif $\left(\mathbf{S}_{4}\right)$}

\section{a. Indikator keluwesan}

Indikator keluwesan terdiri dari soal $1 \mathrm{a}, 2 \mathrm{a}$, dan $3 \mathrm{a} . \mathrm{S}_{4}$ menyelesaikan soal 1a dan $3 \mathrm{a}$ menggunakan satu cara penyelesaian dan pada proses perhitungan diperoleh hasil yang benar dapat 
dilihat pada Gambar 6. Sementara itu, pada soal nomor 2a $\mathrm{S}_{4}$ memberikan jawaban dengan satu cara penyelesaian tetapi proses perhitungan belum tepat. Hasil wawancara $S_{4}$ ditemukan bahwa $S_{4}$ tidak menyelesaikan soal nomor 2a karena tidak mengetahui maksud dari soal. Triangulasi dari hasil tes tulis dan wawancara diperoleh bahwa S4 kurang mampu menyelesaikan permasalahan menggunakan lebih dari satu penyelesaian dan pada proses perhitungan memperoleh hasil yang benar.

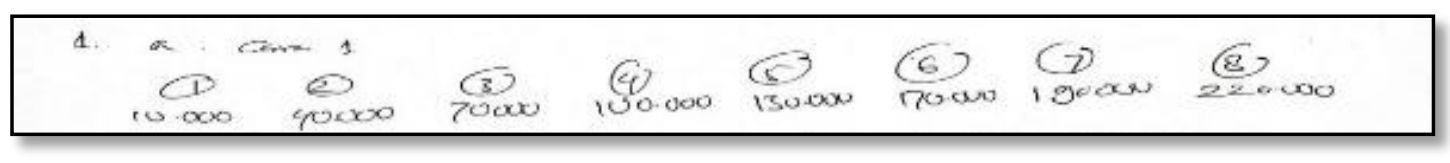

Gambar 6. Pekerjaan $\mathrm{S}_{4}$ soal nomor 1a

\section{b. Indikator kelancaran}

Adapun soal untuk indikator kelancaran terdiri dari soal nomor $1 \mathrm{~b}, 2 \mathrm{~b}$, dan $3 \mathrm{c} . \mathrm{S}_{4}$ menyelesaikan soal $1 \mathrm{~b}$ mengerjakan dengan sebuah ide yang tidak relevan dengan pemecahan masalah. Sedangkan pada soal nomor $2 \mathrm{~b}$ dan $3 \mathrm{c} \mathrm{S}_{4}$ tidak memberikan jawaban untuk soal tersebut. Hasil wawancara diperoleh $\mathrm{S}_{4}$ tidak memberikan jawaban karena tidak mengetahui rumus untuk menyelesaikan soal nomor 2b. Berdasarkan triangulasi dari hasil tes dan wawancara, dapat dikatakan bahwa S4 tidak mampu memberikan lebih dari satu ide yang relevan, penyelesaian benar dan jelas.

\section{c. Indikator elaborasi}

Indikator elaborasi terdiri dari soal nomor $1 \mathrm{c}, 2 \mathrm{c}$, dan $3 \mathrm{~d} . \mathrm{S}_{4}$ menyelesaikan soal nomor $1 \mathrm{c}$ masih terdapat kesalahan dalam jawaban dan tidak disertai dengan perincian. Sementara itu, pada soal nomor $2 \mathrm{c}$ dan $3 \mathrm{~b} \mathrm{~S}_{4}$ tidak memberikan jawaban apapun pada soal tersebut. Pada transkrip wawancara terlihat bahwa $\mathrm{S}_{4}$ tidak memberikan jawaban karena tidak mengetahui rumus untuk menyelesaikan soal tersebut. Berdasarkan triangulasi dari hasil tes dan wawancara, dapat dikatakan bahwa $\mathrm{S}_{4}$ tidak mampu memberikan jawaban yang benar dan rinci.

\section{d. Indikator keaslian}

Indikator keaslian terdiri dari soal $1 \mathrm{~d}, 2 \mathrm{~d}$, dan $3 \mathrm{~b}$. $\mathrm{S}_{4}$ menyelesaikan soal $1 \mathrm{~d}$ dan $3 \mathrm{~b}$ menggunakan cara penyelesaian sendiri, proses perhitungan dan hasilnya benar. Sementara itu, pada soal nomor $2 \mathrm{~d} \mathrm{~S}_{4}$ tidak memberikan jawaban. Pada transkrip wawancara $\mathrm{S}_{4}$ terlihat bahwa $\mathrm{S}_{4}$ tidak menyelesaikan soal nomor $2 \mathrm{~d}$ karena mengetahui rumus atau cara menyelesaikan soal tersebut. Sedangkan pada soal nomor 1d dan 3b memberikan jawaban dengan cara sendiri, proses perhitungan benar. Pada transkrip wawancara diperoleh bahwa $S_{4}$ tidak mengetaui rumus untuk nomor $2 d$. Triangulasi dari hasil tes tulis dan wawancara diperoleh bahwa $S_{4}$ kurang mampu memberi jawaban dengan cara penyelesaian sendiri.Adapun transkrip wawancara untuk indikator keaslian sebagai berikut.

$\mathrm{P}$ : "Mengapa nomor 2 hanya menjawab bagian a?"

$\mathrm{S}_{4}$ : "Tidak tau rumusnya bagian $\mathrm{b}, \mathrm{c}$, dengan d" 


\section{Analisis kemampuan berpikir kreatif subjek kategori tidak kreatif $\left(\mathbf{S}_{5}\right)$}

\section{a. Indikator keluwesan}

Indikator keluwesan terdiri dari soal $1 \mathrm{a}, 2 \mathrm{a}$, dan $3 \mathrm{a} . \mathrm{S}_{5}$ menyelesaikan soal 1a dan $3 \mathrm{a}$ menggunakan satu cara penyelesaian namun proses perhitungan masih kurang tepat dapat dilihat pada Gambar 7. Sementara itu, pada soal nomor 2a $S_{5}$ tidak memberikan jawaban. Transkrip wawancara terlihat bahwa $S_{5}$ menyelesaikan soal nomor 1a dengan satu cara karena tidak mengetahui cara lain untuk menyelesaikan soal tersebut. Berdasarkan triangulasi dari hasil tes tulis dan wawancara diperoleh bahwa $\mathrm{S}_{5}$ tidak mampu menyelesaikan permasalahan menggunakan lebih dari satu penyelesaian dan pada proses perhitungan memperoleh hasil yang benar.

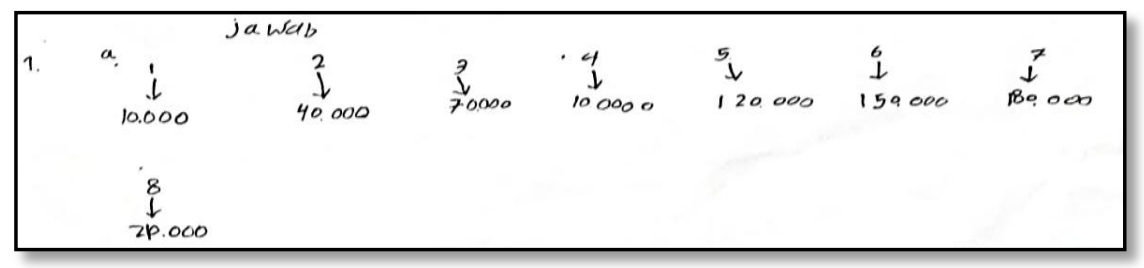

Gambar 7. Pekerjaan $\mathrm{S}_{5}$ soal nomor 1a

\section{b. Indikator kelancaran}

Adapun soal untuk indikator kelancaran terdiri dari soal nomor 1b, 2b, dan 3c. Dapat dilihat pada lembar jawaban $S_{5}$ bahwa $S_{5}$ tidak menyelesaikan soal $1 b, 2 b$ dan 3d. Pada transkrip wawancara terlihat bahwa $S_{5}$ tidak memberikan jawaban karena tidak mengetahui maksud dari pertanyaan soal. Berdasarkan triangulasi dari hasil tes dan wawancara, dapat dikatakan bahwa $\mathrm{S}_{5}$ tidak mampu memberikan lebih dari satu ide yang relevan, penyelesaian benar dan jelas.

\section{c. Indikator elaborasi}

Adapun soal untuk indikator elaborasi terdiri dari soal nomor 1c, 2c, dan 3d. $\mathrm{S}_{5}$ menyelesaikan soal nomor 1c masih terdapat kesalahan dalam jawaban dan tidak disertai dengan perincian. Sementara itu, pada soal nomor $2 \mathrm{c}$ dan $3 \mathrm{~d} \mathrm{~S}_{5}$ tidak memberikan jawaban apapun pada soal tersebut. Pada transkrip wawancara terlihat bahwa $S_{5}$ tidak memahami maksud dari pertanyaan soal nomor $2 \mathrm{c}$ dan $3 \mathrm{~d}$. Berdasarkan triangulasi dari hasil tes dan wawancara, dapat dikatakan bahwa $\mathrm{S}_{5}$ tidak mampu memberikan jawaban yang benar dan rinci.

\section{d. Indikator keaslian}

Indikator keaslian terdiri dari soal $1 \mathrm{~d}, 2 \mathrm{~d}$, dan $3 \mathrm{~b} . \mathrm{S}_{5}$ menyelesaikan soal $1 \mathrm{~d}$ dan $3 \mathrm{~b}$ menggunakan cara penyelesaian sendiri, proses perhitungan dan hasilnya masih kurang tepat. Sementara itu, pada soal nomor $2 \mathrm{~d} \mathrm{~S}_{5}$ tidak memberikan jawaban. Transkrip wawancara $\mathrm{S}_{5}$ terlihat bahwa $\mathrm{S}_{5}$ tidak mengetahui rumus atau cara untuk menyelesaikan soal $2 \mathrm{~d}$. Berdasarkan triangulasi dari hasil tes tulis dan wawancara diperoleh bahwa $S_{5}$ kurang mampu memberikan jawaban dengan cara penyelesaian sendiri.Adapun transkrip wawancara untuk indikator keaslian sebagai berikut. 
Berdasarkan hasil penelitian diperoleh rata-rata pesentase kemampuan berpikir kreatif matematis siswa berada pada kategori cukup kreatif dengan persentase sebesar 46,12\% untuk semua indikator. Indikator keaslian mendapat persentase tertinggi yaitu 51,69\%, sementara indikator kelancaran yaitu 44,93\%, indikator keluwesan yaitu 44,46\%, dan indikator yang paling rendah didapat pada indikator elaborasi yaitu $43,41 \%$. Hasil penelitian ini sejalan dengan penelitian yang dilakukan oleh Putra dkk (2017) dimana kemampuan berpikir kreatif siswa sebagian besar berada pada kategori cukup (sedang) yaitu sebesar 66,66\%. Sementara itu, hasil penelitian oleh Rasnawati, Akbar, dan Putra (2019) mengemukakan bahwa hasil analisis tingkat kemampuan berpikir kreatif siswa SMK masih tergolong rendah melihat rata-rata persentase semua indikator tidak ada indikator yang melebihi 50\%, sehingga dapat dikatakan rata-rata kemampuan berpikir kreatif siswa masih rendah. Pada penelitian ini terlihat bahwa adanya peningkatan pada persentase indikator keaslian karena melebihi $50 \%$.

\section{KESIMPULAN DAN SARAN}

Berdasarkan hasil paparan data dan pembahasan yang telah dipaparkan, disimpulkan bahwa hasil tes kemampuan berpikir kreatif matematis siswa kelas XII MIA SMA Negeri 2 Kolaka terdiri dari 4 indikator diantaranya: (1) keluwesan dengan persentase 44,46\%; (2) keaslian dengan persentase 51,69\%; (3) kelancaran dengan persentase 44,93\%; (4) elaborasi sebesar 43,41\%. Rata-rata hasil tes kemampuan bepikir kreatif matematis ssiwa di kelas XII MIA SMA Negeri 2 Kolaka untuk semua indikator berada pada kategori cukup kreatif dengan persentase sebesar 46,12\%.

Saran-saran yang dapat disampaikan berdasarkan hasil penelitian ini adalah hendaknya guru membiasakan memberikan soal yang menuntut siswa untuk berpikir kreatif. Sedangkan saran untuk peneliti selanjutnya yaitu perlu diadakan penelitian lanjutan dalam rangka mengembangkan kemampuan berpikir kreatif matematis siswa.

\section{DAFTAR PUSTAKA}

Eragamreddy, N. (2013). Teaching creative thinking skills. IJ-ELTS: International Journal of English Language \& Translation Studies, 1(2). 124-145.

Fatwa, V. C., Septian, A., \& Inayah, S. (2019). Kemampuan literasi matematis siswa melalui model pembelajaran problem based introduction. Mosharafa: Jurnal Pendidikan Matematika, 8(3), 389-398.

Gais, Z., \& Afriansyah, E. A. (2017). Analisis kemmapuan siswa dalam menyelesaiakan soal high order thinking ditinjau dari kemampuan awal matematis siswa. Musharafa: Jurnal Pendiidikan Matematika, 6(2), 255-265.

Idrisah, I. (2014). Pengaruh model pembelajaran inkuiri terhadap kemampuan berpikir kreatif siswa (Quasi eksperimen di SMA Darul Muttaqin Bekasi). Skripsi tidak diterbitkan. Jakarta: Program Pascasarjana UIN Syarif Hidayatullah. 
Maudiarti, S., Suma, A., \& Prawiradilaga, D. S. (2015). Buku kerja: Prinsip desain pembelajaran intructional deign principles. Jakarta: Prenadamedia Group.

Moma, I. (2015). Pengembangan instrumen kemampuan berpikir kreatif untuk siswa smp. Delta-Pi Jurnal Matematika dan Pendidikan Matematika, 4(1). 27-41.

Nasruddin, N., Mashuri, S., \& Jahring, J. (2019). Implementation of team assited individualization instructional strategies supported by Geogebra software to improve mathematical problem solving ability. Jurnal Pendidikan Progresif, 9(1), 16-21.

Nasruddin, N., Mashuri, S., \& Nafiah, U. (2020). Peningkatan hasil belajar matematika pada materi segitiga melalui pendekatan penemuan terbimbing Siswa SMP. Jurnal Penelitian Dan Pengkajian Ilmu Pendidikan: E-Saintika, 4(2), 80.

Neolaka, A. \& Neolaka, G. A. A. (2017). Landasan Pendidikan: Dasar Pengenalan Diri Sendiri Menuju Perubahan Hidup. Depok: Kencana.

Nurfitria, A., \& Nindiasari, H. (2018). Peningkatan kemampuan berpikir kreatif matematis dan selfconfidence siswa smp melalui pendekatan open-ended ditinjau dari tahap perkembangan kognitif. GAUSS: Jurnal Pendidikan Matematika, 01(02). 83-96.

Putra, H. D., Akhdiyat, A. M., Setiany, E. P., \& Andiarani, M. (2018). Kemampuan berpikir kreatif matematik siswa smp di cimahi. Kreano, 9(1). 47-53.

Rachman, A. F., \& Amelia, R. (2020). Analisis kemampuan berpikir kreatif matematis siswa SMA di kabupaten bandung barat dalam menyelesaikan soal pada materi trigonometri. MAJU: Jurnal Ilmiah Pendidikan Matematika, 7(1). 83-88.

Rasnawati, A., Rahmawati W., Akbar, P., \& Putra, H. D. (2019). Analisis kemampuan berpikir kreatif matematis siswa smk pada materi sistem persamaan linear dua variabel (spldv) di kota cimahi. Jurnal Cendikia: Jurnal Pendidikan Matematika, 3(1). 164-177.

Sari, D. C. (2015). Karakteristik soal TIMSS. Seminar Nasional Matematika dan Pendidikan Matematika UNY. 303-308.

Setiawan, S. (2012). Meningkatkan kemampuan koneksi dan pemecahan masalah matematik siswa melalui pembelajaran kooperatif model cooperative integrated reading and composition (circ). Tesis SPS UPI: Tidak diterbitkan. 